\title{
Penggunaan Aplikasi Quizizz Sebagai Metode Evaluasi dalam Pembelajaran Daring terhadap Hasil Belajar pada Muatan PKn Kelas V SD
}

\author{
Nurul Izzah Wahyuillahi, Imam Nawawi, Putri Mahanani \\ Universitas Negeri Malang, Jl. Semarang No. 5 Malang, Jawa Timur, Indonesia \\ *Penulis korespondensi, Surel: izzahn076@gmail.com
}

Paper received: 5-7-2021; revised: 23-7-2021; accepted: 30-7-2021

\begin{abstract}
This research was conducted with the aim of knowing The Effect of Using Quizizz App in Online Learning on 5th Graders' PKn Final Score at SD Negeri Bunulrejo 1 Malang. This study used quasiexperiment as a research method and nonequivalent control group as a research design. The subject of the study were 91 th graders in total; 24 students from $5 \mathrm{~A}$ class and 26 students from 5B class. The instruments used was post-test. The data analysis technique used are mean difference test and descriptive analysis. The result showed that the average PKn post-test score in experimental group was 95,27 with 25,08 gain score while the average PKn post-test score in control group was 65,75 with 16,29 gain score. It showed that the average PKn final score and gain score in the experimental group is higher than in the control group after the test is being held. We can conclude that there are positive impact on using Quizizz app in online learning on 5th graders' PKn final score at SD Negeri Bunulrejo 01 Malang.
\end{abstract}

Keywords: Quizizz; evaluation method; online learning; the result of study

\begin{abstract}
Abstrak
Penelitian ini dilakukan dengan tujuan guna mengetahui Pengaruh Penggunaan Aplikasi Quizizz Dalam Pembelajaran Daring Terhadap Hasil Belajar Pada Muatan PKN Kelas V di SD Negeri Bunulrejo 01 Malang. Penelitian ini menggunakan metode quasi eksperimental design dengan menggunakan desain penelitian nonequivalent control group design. Subjek penelitian adalah kelas VA sejumlah 24 peserta didik dan kelas VB sejumlah 26 peserta didik. Instrumen yang digunakan dalam penelitian ini berbentuk lembar tes. Teknik analisis data menggunakan beda mean dan analisis deskriptif. Berdasarkan hasil penelitian menunjukkan bahwa Aplikasi Quizizz dirasa sangat efektif dan berpengaruh terhadap hasil belajar siswa. Hal ini dapat dilihat dari hasil penelitian yang diperoleh sebagai berikut, nilai rata-rata post-test hasil belajar PKn kelas eksperimen sebesar 95,27 (kriteria sangat baik) dengan peningkatan nilai (gain score) sebesar 25,08, sedangkan kelas kontrol nilai ratarata post-test hasil belajar PKn sebesar 65,75 (kriteria cukup) dengan peningkatan nilai (gain score) sebesar 16,29. Hasil penelitian menunjukkan nilai rata-rata hasil belajar PKn dan gain score kelas eksperimen lebih tinggi dibandingkan kelas kontrol setelah diberikan perlakuan. Sehingga dapat disimpulkan bahwa adanya pengaruh (positif) dalam penggunaan Aplikasi Quizizz terhadap hasil belajar PKn kelas V di SD Negeri Bunulrejo 01 Malang.
\end{abstract}

Kata kunci: Quizizz, metode evaluasi; pembelajaran daring; hasil belajar

\section{Pendahuluan}

Pembelajaran merupakan sebuah proses penambahan ilmu, wawasan, serta keterampilan dengan rangkaian kegiatan yang akan dilakukan secara terencana dan sadar guna merubah kearah yang lebih baik. Namun saat ini, pembelajaran lebih dominan dilaksanakan dengan metode ceramah sehingga peserta didik kurang aktif pada proses pembelajaran. Hal ini selaras dengan apa yang dikemukakan oleh Pembelajaran menurut Rachmawati, dkk (2015) mengemukakan bahwa pembelajaran merupakan proses belajar yang 
dilaksanakan secara tatap muka oleh pendidik dan peserta didik, agar peserta didik mendapatkan ilmu dan pengetahuan dari seorang pendidik. Maka untuk memberikan pembelajaran yang lebih aktif, pendidik dapat menerapkan metode pembelajaran yang relevan. Pada tahun 2020 seluruh Dunia mengalami wabah yaitu pandemic COVID-19. Pandemi ini mewabah pertamakali di Wuhan, China. Kemudian, dengan cepat menyebar ke seluruh dunia termasuk Indonesia hanya dalam waktu yang sangat singkat. Oleh sebab itu dengan adanya COVID-19 ini kemendikbud menganjurkan agar siswa belajar dari rumah secara online. Pembelajaran online (daring) adalah kegiatan belajar mengajar yang dapat dilaksanakan tanpa harus melakukan pembelajaran di sekolah atau bisa disebut belajar dari rumah masing-masing tetapi masih dari jangkauan guru dan orang tua. Hal ini sejalan dengan apa yang dikemukakan oleh Pujiasih (2020), model pembelajaran daring merupakan kegiatan yang dapat dilaksanakan sebagai sarana menyampaikan pembelajaran, dengan materi yang telah tersedia di internet, sehingga materi relatif mudah ditemukan serta dapat meningkatkan kemandirian peserta didik di dalam melaksanakan proses belajar. Maka proses belajar secara daring dapat menjadi terobosan baru dan menjadi pilihan metode yang dapat dilaksanakan oleh pendidik untuk mengatasi permasalahan pendidikan pada masa pandemi. Karena, bentuk pembelajaran seperti ini dapat dilaksanakan dimana saja dan kapan saja tanpa harus melaksanakan pembelajaran di sekolah. Isman (2016) mengemukakan bahwa pembelajaran daring merupakan proses belajar mengajar yang pada pelaksanaannya memanfaatkan media internet. Sedangkan, menurut Sobron (2019) Pembelajaran daring merupakan pendidikan formal yang diselenggarakan dengan jarak jauh sehingga membutuhkan media telekomunikasi. Dari penjelasan tersebut dapat dikatakan bahwa pembelajaran daring memanfaatkan sebuah gadget, jaringan internet dan media platform diharapkan dapat menjadi jalan keluar untuk memecahkan permasalahan tersebut. Adapun harapan dari pembelajaran daring tersebut agar dapat memecahkan permasalahan belajar mengajar pada saat pandemi, terutama bidang pendidikan dan diharap siswa tetap bisa mendapatkan ilmu pengetahuan dan tetap melakukan kegiatan belajar mengajar meskipun terhalang COVID-19.

Perkembangan teknologi dalam bidang iptek sangat mempengaruhi pembelajaran tersebut dapat berjalan secara efektif, terutama pada masa COVID-19. Hal tersebut ditunjang oleh peserta didik yang sudah cukup menguasai dalam mengakses dan memanfaatkan jaringan-jaringan tersebut dengan baik. Meskipun begitu guru juga masih merasakan berbagai tantangan seperti fokus peserta didik yang berkurang karena tidak melakukan tatap muka secara langsung. Dengan begitu, harus adanya sebuah media yang dapat memotivasi peserta didik untuk tetap fokus dan meningkatkan hasil belajarnya di dalam suatu proses pembelajaran. pemanfaatan media berbasis e-learning, menjadi upaya yang dapat dilaksanakan oleh pendidik sebagai sarana untuk melihat perkembangan belajar peserta didiknya selama belajar dari rumah. Adapun media berjenis e-learning yang sering digunakan oleh guru salah satunya Aplikasi Quizizz, dimana merupakan sebuah Aplikasi multiplayer. Aplikasi ini dapat diakses melalui website yang dapat dilakukan secara bersamaan dengan teman-teman di sekolah sehingga dapat mengetahui ranking yang diperoleh dalam menjawab quiz tersebut. Tetapi karena adanya pandemi ini guru juga dapat memanfaatkannya sebagai penugasan untuk siswa selama belajar dari rumah. Adapun hasil penugasan tersebut dapat menjadi hasil penilaian yang diambil oleh pendidik, dengan begitu pendidik dapat melihat hasil peningkatan kemampuan belajar peserta didik melalui ranking saat mengerjakan Quiz tersebut. Penelitian ini ditunjang peneliti terdahulu oleh Hidayat (2016), dengan judul "Pemanfaatan Media Digital oleh Guru pada Siswa Kelas X di SMA Negeri 1 Pleret Guna 
Meningkatkan Hasil Belajar PKn Secara Efisien". Penelitian ini relevan dengan penelitian penulis karena sama-sama digunakan untuk mengetahui hasil belajar siswa pada pembelajaran PKn. Adapun hasil penelitian oleh Syaifulloh (2020), dengan judul "Pengembangan Alat Evaluasi Menggunakan Aplikasi Quizizz pada Pembelajaran IPS Terpadu Kelas VII di MTS Negeri 7 Malang". Penelitian ini relevan dengan penelitian penulis karena sama-sama memanfaatkan sebuah aplikasi dalam pembelajaran dengan menggunakan Aplikasi Quizizz. Berdasarkan penelitian diatas, maka peneliti terdorong untuk melakukan penelitian dengan judul "Pengaruh Penggunaan Aplikasi Quizizz Sebagai Metode Evaluasi Dalam Pembelajaran Daring Terhadap Hasil Belajar Pada Muatan PKn Kelas V Di SD Negeri Bunulrejo 01 Malang".

\section{Metode}

Rancangan penelitian dalam penelitian ini menggunakan metode kuantitatif Sugiyono (2011), data yang diperoleh harus melalui penelitian yang memang benar-benar valid. Adapun metode penelitian terbagi menjadi dua yaitu metode penelitian kualitatif dan kuantitatif. Sugiyono (2011), metode kuantitatif merupakan satu proses pengelolaan data berupa angka dan analisis dengan menggunakan statistik pada penelitian. Kaidah ilmiah yang akan digunakan dalam metode ini harus objektif, konkrit, terukur, rasional, dan sistematis. Oleh sebab itu metode penelitian yang akan digunakan pada penelitian ini bertujuan untuk mengidentifikasi, mengumpulkan data, analisis dan menarik kesimpulan. Penelitian ini menggunakan desain quasi eksperimental desain yaitu pengembangan dari true experimental design yang sulit digunakan. Sugiyono (2010) mengemukakan bahwa, desain penelitian ini memiliki kelompok kontrol, akan tetapi tidak sepenuhnya digunakan sebagai alat kontrol variabel-variabel luar yang dapat berpengaruh dalam kelompok eksperimen. Desain ini digunakan karena dalam data nyata yang diperoleh sulit untuk mendapatkan kelompok kontrol yang diperlukan dalam penelitian. Oleh sebab itu, cara yang dapat dilakukan untuk menentukan kelompok kontrol dari penelitian perlu dikembangkan desain quasi eksperimental dengan bentuk desain nonequivalent control group design. Menurut Sugiyono (2010), mengemukakan bahwa nonequivalent control group design hampir sama dengan pretest kontrol group design, namun pada desain ini kelompok eksperimen atau kelompok kontrol tidak dipilih cara acak. Melalui kelompok eksperimen dan kelompok kontrol, peneliti menentukan bahwa kelas VA sebagai kelompok eksperimen dan VB sebagai kelompok kelas kontrol. Adapun beberapa prosedur yang akan dilakukan dalam penelitian ini yaitu:

\subsection{Tahap Pertama (Pengumpulan Data)}

Dalam tahap pengumpulan data ini peneliti melakukan kegiatan dengan pelaksanaan sebagai berikut yaitu melakukan kegiatan pembelajaran pada Kelas Eksperimen dan Kelas Kontrol. Tahap pengumpulan data pertama dilakukan pada Kelas Eksperimen dengan memberikan tes Awal (pre-test) dengan menggunakan Aplikasi Quizizz, sedangkan pada Kontrol hanya mengerjakan pada lembar soal tanpa menggunakan Aplikasi Quizizz. Kemudian, melaksanakan kegiatan pembelajaran PKn secara online, setelah melakukan kegiatan pembelajaran online, kelas eksperimen mengerjakan tes akhir (post-test) dengan menggunakan Aplikasi Quizizz dan kelas kontrol mengerjakan tes akhir (post-test) pada lembar soal tanpa menggunakan Aplikasi Quizizz. 


\subsection{Tahap Kedua (Pengolahan Data)}

Pada tahap ini peneliti melakukan pengolahan data yang telah diperoleh dari hasil pretest dan post-test yang telah diberikan kepada kelas ekperimen dan kelas kontrol.

Setelah melakukan prosedur pengelolaan data, selanjutnya peneliti akan melakukan teknik analisis data. Sugiyono (2010), mengemukakan bahwa analisis data merupakan penggolongan data berdasarkan variabel dan jenis responden, mentabulasi data berdasarkan variabel dari semua responden, menyajikan data dari tiap variabel yang diteliti dan mengkalkulasi uji hipotesis yang sudah diajukan. Kemudian melakukan pengumpulan data penelitian yang akan dianalisis. Kemudian hasil analisis data digunakan untuk menguji hipotesis atau menjawab permasalahan penelitian.

Analisis yang digunakan pada penelitian ini berupa beda mean dan deskriptif yang akan diberikan kepada kelas eksperimen dan kelas kontrol, dengan begitu dapat dianalisis apakah terdapat peningkatan terhadap hasil belajar PKn siswa yang telah menggunakan Aplikasi Quizizz. kemudian peneliti tidak perlu mengambil sampel, tetapi menggunakan populasi. Subjek penelitian yaitu kelas VA dan kelas VB. Kelas VB sebagai kelas eksperimen diberikan perlakuan dengan menggunakan Aplikasi Quizizz, sedangkan kelas VA sebagai kelas kontrol diberikan perlakuan dengan menjelaskan dan menulis materi melalui penjelasan dari guru di whatsapp group tanpa menggunakan aplikasi Quizizz.

\section{Hasil dan Pembahasan}

Berdasarkan penelitian yang telah dilaksanakan di SD Negeri Bunulrejo 01 Malang pada kelas V A dan V B, pada penelitian ini kelas V A digunakan sebagai kelompok kontrol dimana pada evaluasi pembelajaran peserta didik mengerjakan soal hanya melalui lembar pekerjaan siswa dengan jawaban yang ditulis melalui kertas folio kemudian dikumpulkan di sekolah, sedangkan pada kelas V B sebagai kelompok eksperimen diberikan evaluasi pembelajaran dengan menggunakan Aplikasi Quizizz, tanpa mengumpulkan pekerjaan ke sekolah. Materi pembelajaran yang digunakan oleh peneliti yaitu sikap toleransi dalam keberagaman sosial \& budaya pada tema 8, subtema 1 pada muatan PKn dengan perlakuan sebanyak satu pertemuan. Hal ini sesuai dengan apa yang dikemukakan Oleh Wulandari (2018), bahwa kemampuan yang harus dimiliki oleh seorang harus dapat mengembangkan materi pembelajaran sesuai dengan kebutuhan siswa serta mengikuti perkembangan zaman. Berikut ini hasil peningkatan gain score pada kelas eksperimen dan kelas kontrol:

Tabel 1. Data Hasil Gain Score

\begin{tabular}{lllll}
\hline \multirow{2}{*}{ Data } & \multicolumn{2}{c}{ Kelas Eksperimen } & \multicolumn{2}{c}{ Kelas Kontrol } \\
\cline { 2 - 5 } & Pre-test & Post-test & Pre-test & Post-test \\
\hline Nilai Terendah & 46 & 73 & 28 & 40 \\
Nilai Tertinggi & 100 & 100 & 66 & 100 \\
Nilai Rata-rata & 70,19 & 95,27 & 49,46 & 65,75 \\
Gain Score & 25,08 & 16,29 & & \\
\hline
\end{tabular}

Berdasarkan tabel tersebut, rata-rata nilai post-test yang diperoleh kelas eksperimen sebesar 95,27 dengan kriteria sangat baik. Kemudian rata-rata nilai post-test pada kelas kontrol dengan kriteria cukup sebanyak 65,75. Nilai rata-rata yang dihasilkan pada post-test kelas eksperimen memperoleh hasil lebih tinggi yaitu 95,27, daripada hasil rata-rata nilai post- 
test kelas kontrol yaitu 65,75 , dengan begitu perbedaan rata-rata nilai dari post-test kedua kelas tersebut yaitu 29,52. Keduanya mengalami peningkatan (gain score) rata-rata nilai hasil belajar PKn yang semula sebesar 70,19 (baik) pada pre-test kemudian setelah diberikan perlakuan nilai rata-rata meningkat menjadi 95,27 (sangat baik) pada post-test dengan nilai peningkatan sebesar 25,08. Sama halnya dengan kelas kontrol, mengalami peningkatan ratarata dari nilai pre-test sebesar 49,46 (kurang) menjadi 65,75 (cukup) setelah diberikan perlakuan, dengan nilai peningkatan sebanyak 16,29. Nilai tertinggi yang diperoleh kelas eksperimen saat pre-test sebesar 100 (sangat baik) tetapi hanya satu peserta didik saja yang mendapatkan nilai tersebut. setelah diberikan perlakuan peserta didik yang memperoleh hasil sangat baik dengan nilai 100 meningkat menjadi 16 peserta didik. Pada kelas eksperimen yang mendapatkan nilai terendah juga mengalami peningkatan dari 46 peserta didik yang mendapatkan nilai kurang menjadi 73 dengan kriteria baik, dengan nilai peningkatan sebanyak 27. Nilai tertinggi pre-test pada kelas kontrol sebesar 66 (cukup) setelah mendapat perlakuan nilai tersebut meningkat menjadi 100 (baik) tetapi hanya satu siswa saja yang mendapatkan nilai tersebut. Data hasil pre-test dan post-test kedua kelas tersebut selanjutnya ditampilkan dalam diagram berikut.

Penelitian ini dilakukan pada tanggal 24 Maret 2021 - 26 Maret 2021. Diawali dengan memberikan pre-test hasil belajar PKn materi tentang sikap toleransi dalam keberagaman sosial \& budaya. Adapun subjek penelitian dalam penelitian ini yaitu siswa-siswi kelas VA sebagai kelompok kontrol dan kelas VB sebagai kelompok eksperimen. Penelitian ini dilaksanakan selama satu pertemuan pada setiap kelompok, dengan materi dan waktu pelaksanaan yang sama hanya cara guru dalam memberikan evaluasi pembelajaran yang berbeda. Pada kelompok eksperimen guru menggunakan Aplikasi Quizizz, sedangkan pada kelompok kontrol guru tidak menggunakan Aplikasi Quizizz (Pengerjaan di buku tugas). Perbedaan cara guru dalam memberikan perlakuan menggunakan aplikasi Quizizz bertujuan agar pengaruh penggunaan Aplikasi terhadap hasil belajar PKn di SD Negeri Bunulrejo 01 Malang dapat diketahui.

Pada awal kegiatan penelitian ini melaksanakan pre-test hasil belajar PKn kelompok eksperimen dan kelompok kontrol. Pretest pada kelas eksperimen dilaksanakan pada hari Rabu, 24 Maret 2021, sedangkan pada kelas kontrol dilaksanakan hari Kamis, 25 Maret 2021. Pelaksanaan pre-test pada kedua kelompok dilaksanakan satu kali pertemuan selama 80 menit di tiap kelompok. Kelompok eksperimen yaitu kelas VB dengan jumlah 26 peserta didik. Materi yang diberikan yaitu sikap toleransi dalam keberagaman sosial \& budaya. Peneliti menjelaskan materi dengan menggunakan video dan PPT pada Aplikasi Quizizz yang peneliti buat sendiri dan kemudian di share ke Whatsapp Group, dikarenakan pembelajaran offline tidak memungkinkan. Kemudian siswa diminta untuk mengerjakan tugas yang telah diberikan guru dan mengerjakan soal evaluasi pada Aplikasi Quizizz. Kemudian guru mengontrol hasil belajar siswa pada Aplikasi tersebut.

Pembelajaran dengan menggunakan Aplikasi Quizizz ini menggunakan kata kunci sehingga cukup membantu peserta didik dalam mengingat materi. Divany (2020), Aplikasi Quizizz merupakan sebuah aplikasi berbasis game yang didesain untuk membantu guru agar dapat menciptakan kegiatan yang interaktif. Berdasarkan hasil penelitian menunjukkan bahwa pembelajaran di kelompok eksperimen peserta didik sangat bersemangat dalam mengikuti kegiatan pembelajaran sehingga proses pembelajaran dapat berjalan lancar. Peserta didik juga 
terlihat aktif dalam pembelajaran, hal ini ditunjukkan dengan peserta didik sering bertanya ketika mengalami kesulitan.

Penelitian ini juga diberikan kepada kelas kontrol, dimana kegiatan penelitian kelas kontrol diawali dengan pertemuan pertama pada hari Kamis, 25 Maret 2020. Cara penyampain materi pembelajaran di kelas kontrol berbeda dengan kelas eksperimen, letak perbedaannya dapat dilihat dari bagaimana peneliti menyampaikan materi dalam proses pembelajaran. Cara penyampaian materi dalam kelas kontrol peneliti menyampaikan materi dengan memberikan materi dan penjelasan melalui video pembelajaran dan bacaan dari kertas saja (berbentuk word document) kepada guru kelas VA. Pada kelas kontrol, peneliti tidak langsung mengajar di grup kelas. Akan tetapi, disampaikan melalui guru kelas VA kepada peserta didik. Saat melakukan proses pembelajaran, materi yang akan diajarkan pada pertemuan pertama antara kedua kelas tersebut sama, yaitu sikap toleransi dalam keberagaman sosial \& budaya. Pembelajaran yang dilaksanakan pada kelompok kontrol berlangsung kurang responsif, karena masih banyak beberapa peserta didik yang kurang aktif di Whatsapp grup, dan ketika mengumpulkan tugas terlambat.

Langkah selanjutnya setelah diberi perlakuan pada kedua kelas tersebut kemudian peneliti melakukan post-test untuk mengetahui hasil belajar PKn pada kedua kelas tersebut. Post-test untuk mengetahui hasil belajar PKn dilaksanakan secara bersamaan pada kelompok eksperimen dan kelompok kontrol pada hari Jum'at, 26 Maret 2021. Hasil post-test muatan PKn tersebut kemudian diolah untuk mengetahui nilai rata-ratanya. Berdasarkan hasil posttest pada kedua kelompok tersebut diperoleh data dari nilai rata-rata sebesar 95,27 oleh kelompok eksperimen, sedangkan untuk kelompok kontrol diperoleh nilai rata-rata sebesar 65,75 . Maka dapat disimpulkan bahwa nilai rata-rata yang dihasilkan kelompok eksperimen lebih tinggi dari pada nilai rata-rata kelompok kontrol, dengan perbandingan nilai sebanyak 29,52. Hasil post-test belajar PKn kelompok eksperimen dan kelompok kontrol mengalami peningkatan dari hasil pre-test awal. Pada kelompok eksperimen nilai rata-rata mengalami peningkatan dari hasil pre-test sebanyak 70,19 dan mengalami peningkatan menjadi 95,27 setelah diberi perlakuan. Sehingga ada peningkatan gain score sebanyak 25,05 . Begitu juga nilai rata-rata kelas kontrol mengalami peningkatan gain score sebanyak 16,28 , dari pre-test awal 49,46 menjadi 65,75 . Hal tersebut selaras dengan pernyataan yang dikemukakan oleh Sugandi (2007), bahwa kualitas pembelajaran merupakan suatu kejadian dimana menuntut peserta didik agar selalu siap untuk belajar. Berdasarkan penjelasan diatas dan hasil penelitian dapat disimpulkan bahwa implementasi penggunaan Aplikasi Quizizz di kelas eksperimen sangat signifikan dan berpengaruh. Sehingga dapat dilihat peningkatan nilai rata-rata hasil belajar PKn di kelompok eksperimen dengan menggunakan Aplikasi Quizizz yang sangat signifikan mengalami peningkatan dibandingkan dengan peningkatan yang terjadi pada kelompok kontrol.

Berdasarkan penjelasan tersebut, setelah menggunakan metode pembelajaran menggunakan Aplikasi Quizizz, nilai rata-rata post-test kelompok eksperimen menunjukkan peningkatan gain score yang lebih tinggi ketika menggunakan Aplikasi Quizizz dibandingkan pada kelompok kontrol yang tanpa menggunakan Aplikasi Quizizz. Hal ini sejalan dengan apa yang dikemukakan oleh Mega Wulandari (2020), bahwa Aplikasi Quizizz merupakan aplikasi digital yang digunakan untuk menentukan nilai dan menilai kemampuan peserta didik dalam memahami materi. Maka sebab itu, dapat disimpulkan bahwa dengan adanya pembelajaran yang menggunakan Aplikasi Quizizz dapat meningkatkan nilai hasil belajar PKn. Hal itu sejalan 
dengan pernyataan Matt Jarvis (2011) aspek kognitif merupakan kemampuan berpikir abstrak dimana otak akan menjalankan fungsinya untuk berfikir, mengetahui, menganalisis, memahami, bernalar, ber-ide, berkreasi dan bertindak. Adapun menurut Suryadi (2017) game adalah suatu permainan yang dibuat dengan metode animasi. Kesimpulan dari penjabaran diatas Aplikasi Quizizz yang berbasis game mampu meningkatkan ranah kognitif. Berdasarkan nilai yang dihasilkan pada penelitian ini menunjukkan bahwa Aplikasi Quizizz dirasa sangat efektif dan berpengaruh terhadap hasil belajar siswa. Hal tersebut dapat dilihat dari hasil gain score nilai rata-rata belajar PKn kelompok eksperimen yang lebih tinggi dibandingkan dengan kelompok kontrol, sehingga dapat diambil kesimpulan bahwa adanya pengaruh (positif) penggunaan Aplikasi Quizizz sebagai metode evaluasi dalam hasil belajar PKn siswa kelas V di SD Negeri Bunulrejo 01 Malang.

\section{Simpulan}

Berdasarkan hasil analisis dan pembahasan laporan penelitian menunjukkan bahwa, hasil pre-tes dan post-test dari kedua kelompok tersebut mengalami peningkatan setelah diberi perlakuan. Adapun pengaruh penggunaan aplikasi Quizizz terhadap hasil belajar dapat dilihat dari hasil belajar PKn pada post-test kelompok eksperimen lebih tinggi sebesar 95,27, dibandingkan kelompok kontrol dengan nilai sebesar 65,75, dengan begitu dapat dilihat bahwa pada kelompok eksperimen mengalami peningkatan dari hasil rata-rata pre-test ke post-test (gain score) yang lebih tinggi yaitu sebesar 25,08, dibandingkan dengan hasil nilai rata-rata pada kelompok kontrol yang memperoleh perbandingan sebesar 16,29. Dengan begitu dapat diambil kesimpulan bahwa adanya pengaruh (positif) dalam penggunaan Aplikasi Quizizz terhadap hasil belajar pada muatan PKn di SD Negeri Bunulrejo 01 Malang.

\section{Daftar Rujukan}

Arifin, Z. (2011). Penelitian Pendidikan. Bandung: Remaja Rosdakarya.

Arikunto, S. (2011). Prosedur Penelitian Suatu Pendekatan Praktik. Jakarta: Rineka Cipta.

Aslamiyah S. (2020). Pendampingan Peningkatan Pemberdayaan Masyarakat Desa Betoyoguci, Kabupaten Gresik. Journal Of Community Service, 2(3).

Dewi, dkk. (2014). Model Pembelajaran Take And Give Berbatuan Media Grafis Terhadap Hasil Belajar PKn SD Volume 2 (1). e Journal Mimbar PGSD Universitas Pendidikan Ganesha Jurusan PGSD, 2(1) .

Divany, dkk. (2020).Pemanfaatan Aplikasi Quizizz Sebagai Media Pembelajaran Ditengah Pandemi Pada Siswa SMA. Jurnal Ilmiah Ilmu Terapan Universitas Jambi, 4(2).

Ferdiansyah, dkk. (2020). Pemanfaatan Media Pembelajaran Berbasis E-leaning dalam Meningkatkan Hasil belajar pada Matakuliah Media Pembelajaran Musik. Jurnal Pendidikan Bahasa, Sastra, dan Seni, 21 (1).

Hamzah, U.B. (2010). Model Pembelajaran Menciptakan Proses Belajar Mengajar Yang Kreatif dan Efektif. Jakarta: Bumi aksara.

Isman, M. (2016). Pembelajaran Moda Dalam Jaringan (Moda Daring). Sumatra Utara: Muhammadiyah University Press.

Japar, dkk. (2019). Media dan Teknologi Pembelajaran PPKN. Surabaya: CV Jakad.

Jarvis, M. (2011). Teori-Teori Psikologi, Cetakan X. Bandung: Nusa Media

Mahanani, dkk. (2020). Creativity of Junior High School Teacher in Learning in the Time of Covid-19. International Conference In Information Technology And Education Volume: 508 Tahun 2020.

Paryanto. (2020). Implementasi Model Pembelajaran Kooperatif Tipe STAD. Malang: Ahlimedia Press.

Payadnya, I \& Jayantika, I. (2018). Panduan Penelitian Eksperimen Beserta Analisis Statistik Dengan SPSS. Sleman Yogyakarta: CV Budi Utama.

Prasetia. (2016). Pengaruh media Audio Visual Terhadap Hasil belajar Matematika. Jurnal Kajian Pembelajaran Matematika, 1(2) 
Pujiasih, E. (2020). Membangun Generasi Emas Dengan Variasi Pembelajaran Online Di Masa Pandemi Covid19. Ideguru : Jurnal Karya Ilmiah Guru

Rachmawati T \& Daryanto. (2015). Teori Dan Proses Pembelajaran Yang Mendidik. Yogyakarta: Gava Media.

Riyana, C. (2012). Media Pembelajaran. Jakarta Pusat: Direktorat Jendral Pendidikan Islam Kementrian Agama RI.

Siyoto, dkk. (2015). Dasar Metodilogi Penelitian. Sleman Yogyakarta: Literasi Media Publishing.

Sobron. (2019). Persepsi Siswa dalam Studi Pengaruh daring Learning Terhadap Minat Belajar IPA. Jurnal Pendidikan Islam dan Multikulturalisme. 1(2).

Sriyanti, I. (2019). Evaluasi Pembelajaran Matematika. Ponorogo: Uwais Insiprasi Indonesia.

Sugiyono. (2010). Metode Penelitian Pendidikan Kuantitatif, Kualitatif, dan R\&D. Bandung: Alfabeta.

Sukestiyarno, dkk. (2020). Model Pembelajaran PME. Bandung: Scopindo Media Pustaka.

Sukmadinata, N. (2016). Metode Penelitian Pendidikan. Bandung: PT Remaja Rosdakarya Offset.

Sulfemi, W. (2019). Penerapan Model Pembelajaran Discovery Learning Meningkatkan Motivasi dan Hasil Belajar Pendidikan Kewarganegaraan. Jurnal STKIP PGRI Tulungagung, 5(1).

Suryadi, A. (2017). Perancangan Game Edukasi Menggunakan Model Waterfall. Jurnal Petik, 3(1).

Syarifudin, A. (2020). Implentasi Pembelajaran Daring Untuk Meningkatkan Mutu Pendidikan Sebagai Dampak Diterapkannya Social Distancing. Jurnal Pendidikan Bahasa Dan Sastra, 5(1).

Trianto. (2013). Desain Pengembangan Pembelajaran Tematik Bagi Anak Usia Dini. Jakarta: Kencana

Wulandari M. 2020. Technology for English language Learning. Yogyakarta: Sanata Dharma University Press

Wulandari Siti. (2020). Pembelajaran Daring Sebagai Upaya Study From Home (SFH) Selama Pandemi Covid 19. Jurnal Pendidikan Administrasi Perkantoran (JPAP), 8(3)

Yuliani, M, dkk. (2020). Pembelajaran Daring untuk Pendidikan: Teori dan Penerapan. Medan: Yayasan Kita Menulis

Zendrato, W. (2020). Gerakan Mencegah Daripada Mengobati Terhadap Pandemi Covid-19. Jurnal Education And Development Institut Pendidikan Tapanuli Selatan, 8(2). 